\title{
David Kennedy
}

(1904-74)

David Kennedy was, in the original and best sense of the word, an amateur: he devoted himself to the study of history because he loved it. By training a scientist, by profession a teacher, he spent almost the whole of his working life as a highly-respected member of the staff of St Malachy's College, Belfast; but, outside the college, he was best and most widely known as a historian. There was, however, no clash between the two fields of activity. He was much interested in the history of education. His Towards a university (Belfast, 1946) is a useful contribution to the study of the 'university question' in Ireland; and his presentation of 'Robert Park's account of schools in the Ballymoney parish, I824' (I.H.S., vi, no. 2 I (Mar. I942), pp 23-32) provides essential basic material for the history of primary education in rural Ireland in the early nineteenth century. He was well-known as a broadcaster and contributed to three series of talks subsequently published in book form by the British Broadcasting Corporation: 'Ulster and the antecedents of home rule, 1850-86', in Ulster since 1800: a political and economic survey (London, 1954); 'The catholic church', in Ulster since 1800 , second series: a social survey (London, 1957); 'The early eighteenth century', in Belfast: the origin and growth of an industrial city (London, 1967). His meticulous work on Joseph Black ( $1728-99$ ), professor of chemistry at Glasgow, is important not only for the history of science and of scientific education but also for the social and economic history of eighteenth-century Ulster. His work on this subject was still in progress at the time of his death; but he had published, in conjunction with Douglas McKie, an important paper, 'On some letters of Joseph Black and others' (Annals of Science, vi, no. 3 (Sept. ig6o)).

The importance of David Kennedy's influence rested no less on his personality than on his writings. He was a foundation member of the Ulster Society for Irish Historical Studies, a member of the committee and, later, president. Both in the internal affairs of the society and as one of its representatives on the Irish Committee of Historical Sciences and on the editorial board and committee of management of this journal, he played a significant part in guiding the development of historical study in Ireland. He was known by all to be both unselfish and fairminded. He thought little of his own claims, but was always ready to give full consideration to those of others. His principles were firmly held, but never aggressively put forward; and he was generously sensitive to the feelings of those who might differ from him. That the study of Irish history has been freed from the aura of political and sectarian controversy that once surrounded it owes not a little to his clear-minded and kindly scholarship. It was entirely characteristic of him that during 
the bitter public strife in which his last years were passed he more than once displayed a degree of moral courage that, in Ireland at least, is more often praised than practised.

Though this tribute is primarily concerned with David Kennedy's work as a historian, it is relevant to mention also his wide-ranging interest in literature, and especially in the drama, an interest that was reflected in his friendships as well as in his writings. He brought to the study of history a sympathetic concern for human life in all its aspects; and he had a command of language that enabled him to express his ideas, whether in speech or on paper, with clarity and elegance, occasionally seasoned by a sharp though kindly wit. His presence will long be missed; but his memory and his writings will remain.

J. G. BeGKett 